\title{
Nurse's knowledge and attitude regarding cervical cancer screening at a tertiary care hospital
}

\author{
Bhabani Pegu*, Niharika Dhiman, Jaya Chaturvedi, Suresh K. Sharma
}

Department of Obstetrics and Gynecology, All India Institute of Medical Sciences Rishikesh, Uttarakhand, India

Received: 16 December 2016

Accepted: 03 February 2017

\author{
*Correspondence: \\ Dr. Bhabani Pegu, \\ E-mail: bpeguamc@gmail.com
}

Copyright: () the author(s), publisher and licensee Medip Academy. This is an open-access article distributed under the terms of the Creative Commons Attribution Non-Commercial License, which permits unrestricted non-commercial use, distribution, and reproduction in any medium, provided the original work is properly cited.

\begin{abstract}
Background: Cervical cancer is one of the commonest cancers among women which cause morbidity and mortality worldwide. Though, it is a preventable disease, most of the women with cervical cancer present in advanced stage due to lack of knowledge about the disease and screening among general population. The objective was to assess the level of knowledge and explore attitude towards cervical cancer screening among female nursing staff.

Methods: A cross sectional, questionnaire based study was conducted on 34 female nursing staff in a tertiary care hospital of Uttarakhand, India in the month of January 2015. With the help of predesigned questionnaire, information was collected regarding demographic profile, knowledge about cervical cancer and attitude towards screening techniques.

Results: In this study, $79 \%$ of the respondents had knowledge about screening methods for cervical cancer and $91 \%$ had knowledge about HPV vaccine. Though $82 \%$ of them were aware of pap smear and $89 \%$ had good attitude towards it, $85.29 \%$ respondent knew about colposcopy as one of the screening technique for cervical cancer. None of the respondent had undergone a pap smear themselves.

Conclusions: The study showed that, female nursing staff had average knowledge and positive attitude towards cervical cancer screening. They were not aware of the routine screening guidelines and had limited understanding of different types of cervical cancer screening techniques. Hence, it is recommended that routine training should be given on regular basis to all the health care providers.
\end{abstract}

Keywords: Attitude, Cervical cancer, Knowledge, Nurses, Screening

\section{INTRODUCTION}

Cervical cancer is an important public health problem. Globally, cancer cervix is one of the commonest cancers among women, with an estimate of 468000 new cases annually and $80 \%$ of these cases occur in developing and underdeveloped countries. ${ }^{1}$ The burden of cervical cancer in India is enormous, accounting for about $20 \%$ of all cancer related deaths in women and is the number one cause of death in middle aged Indian women. ${ }^{2}$ The disease has a pre-malignant stage which usually occurs in younger women under the age of $40 .{ }^{3}$ Cervical cancer is a preventable disease and cured if detected early enough. ${ }^{4}$ The incidence of cervical cancer has declined in western countries due to introduction of screening programs. Pap smear is one of the modern success stories in the field of preventive medicine which detects cervical cancer in its early stage. In 1943, Dr George Papanicolau introduced this technique. ${ }^{5}$ Other methods of screening technique are colposcopy, visual inspection with acetic acid (VIA), visual inspection with lugols iodine (VILI), and Human Papilloma Virus (HPV) DNA testing. ${ }^{6-8}$ 
Knowledge regarding screening of malignancies among health care providers is utmost important in a country like ours. Nurses are the important health personnel to educate and sensitize the general population regarding need for cervical cancer screening. With this background the present study was conducted to assess the level of knowledge and attitude regarding cervical cancer screening among nursing staff.

\section{METHODS}

This was a questionnaire based descriptive cross sectional study, carried out in a tertiary care hospital of Uttarakhand, India in the month of January 2015. The study population included all $(\mathrm{N}=34)$ female nursing staff working in the hospital. The study protocol was approved by the institutional ethical committee. After taking verbal consent, the self- administered structured questionnaire was provided and participants were asked to fill it individually. The questionnaire was validated by two experts. With the help of a predesigned \& pretested questionnaire, information was collected regarding demographic profile, knowledge about cervical cancer screening and attitude towards screening techniques among the nursing staff of hospital. The anonymity and confidentiality of the participants and the collected data were maintained. The obtained data were entered and analysed by using statistical package for social sciences (SPSS) software version 21.

\section{RESULTS}

The mean age of participants was 25years. All of them were B.Sc. nursing. Out of all participants $(\mathrm{N}=34)$, $73.52 \%$ were unmarried and $26.47 \%$ were married. Table 1 shows the demographic profile of the participants.

Table 1: Socio demographic characteristics of study population $(\mathrm{N}=30)$.

\begin{tabular}{|ll|}
\hline Variables & Frequency (\%) \\
\hline Age (years) & \\
\hline $20-25$ & $5(14.7 \%)$ \\
\hline $26-30$ & $16(47.1 \%)$ \\
\hline $31-35$ & $12(35.3 \%)$ \\
\hline $36-40$ & $1(2.9 \%)$ \\
\hline Marital status & \\
\hline Married & $9(26.5 \%)$ \\
\hline Unmarried & $25(73.5 \%)$ \\
\hline Religion & \\
\hline Hindu & $27(79.4 \%)$ \\
\hline Muslim & $5(14.7 \%)$ \\
\hline Christian & $2(5.9 \%)$ \\
\hline
\end{tabular}

The source of information about cervical cancer and its screening methods is shown in Table 2. The result showed that majority $(73.5 \%)$ of respondents got the information from media followed by from books
(11.8\%), 8.8\% from gynaecologist and $5.9 \%$ from health science books and journals.

Table 2: Source of information.

\begin{tabular}{|c|c|}
\hline Source & Frequency (\%) \\
\hline Media & $25(73.5 \%)$ \\
\hline Books & $4(11.8 \%)$ \\
\hline Gynecologists & $3(8.8 \%)$ \\
\hline Journals & $2(5.9 \%)$ \\
\hline Friends and family & $4(11.8 \%)$ \\
\hline
\end{tabular}

Table 3: Knowledge on cervical cancer.

\begin{tabular}{|ll|}
\hline Variables & Frequency $(\%)$ \\
\hline Cervical cancer can be present as & \\
\hline Without any symptoms & None \\
\hline Intermittent bleeding & $19(55.9 \%)$ \\
\hline Discharge per vagina & $12(35.3 \%)$ \\
\hline Post coital bleeding & $7(20.6 \%)$ \\
\hline Dyspareunia & $4(11.8 \%)$ \\
\hline Risk factor & \\
\hline Multiple sex partners & $21(61.8 \%)$ \\
\hline Early coitus & $8(23.5 \%)$ \\
\hline Immunocompromised women & $5(14.7 \%)$ \\
\hline Use of oral contraceptive pills & $7(20.6 \%)$ \\
\hline Multiparity & $5(14.7 \%)$ \\
\hline * Includes multiple responses. & \\
\hline
\end{tabular}

Table 4: Knowledge about cervical cancer screening.

\begin{tabular}{|ll|}
\hline Wariables & Frequency (\%) \\
\hline $\begin{array}{l}\text { Who should be screened } \\
\text { Sexually active women above } 30\end{array}$ & $10(29.4 \%)$ \\
\hline $\begin{array}{l}\text { Sexually active women above } 21 \\
\text { years of age }\end{array}$ & $24(70.6 \%)$ \\
\hline Screening interval & $19(55.9 \%)$ \\
\hline One year & $4(11.7 \%)$ \\
\hline Two year & $11(32.3 \%)$ \\
\hline Three year & $32(94.1 \%)$ \\
\hline Screening methods for cancer cervix \\
\hline Pap smear & $29(85.3 \%)$ \\
\hline Colposcopy & None \\
\hline VIA & -do- \\
\hline VILI & \\
\hline
\end{tabular}

* Includes multiple responses.

In this study $79 \%$ respondents had knowledge about screening methods for cervical cancer. Table 3 shows that, $97.05 \%$ respondent knew that cervical cancer is preventable and can be detected at an early stage. According to respondents the common symptoms associated with cervical cancer were inter-menstrual bleeding, discharge per vagina, post coital bleeding and dyspareunia. Most $(61.8 \%)$ of the respondents knew that risk factor for cervical cancer is due to multiple sex 
partner followed by early coitus and immune compromised women.As shown in Table 4, though $94.11 \%$ of them were aware of Pap smear and $85.3 \%$ of them knew about colposcopy. None of them knew about visual inspection with acetic acid, visual inspection with Lugol's iodine and HPV test as screening methods for cervical cancer.

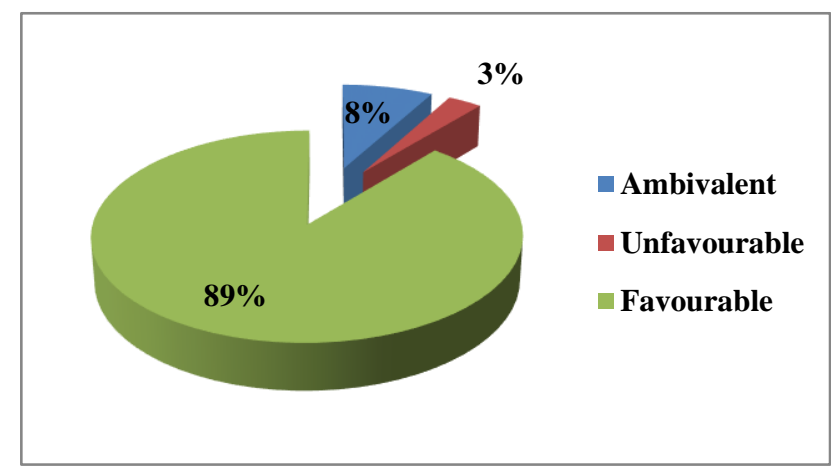

Figure 1: Responses related to attitude regarding screening of cancer cervix.

In this study out of all the respondents, $89 \%$ of them knew about the HPV vaccine but none had received it.

Though $26.47 \%$ respondents were married but none of them had undergone screening test. Respondents who did not have Pap smear done because $68 \%$ felt that it was not needed, $22 \%$ found it embarrassing and 10\% thought it might be costly and painful. Figure 1, shows the attitude regarding screening of cervical cancer, where majority $(89 \%)$ of them had favourable attitude.

\section{DISCUSSION}

Cancer cervix is a preventable disease and a key aspect of its prevention is the detection of the premalignant form by cervical screening. ${ }^{9}$ The present study showed that $79 \%$ respondents have average knowledge. A study conducted by Awodele O in 2011, had shown that $99 \%$ of nurses had good knowledge of cervical cancer which is consistent with the earlier study from South Eastern Nigeria. ${ }^{10,11}$ Another study conducted by Gupta $\mathrm{M}$ in Ghaziabad, India in 2013 showed that $80 \%$ respondent knew about cervical cancer. ${ }^{12}$

Present study showed that, 92\% nurses believed that cervical cancer is preventable and detected in early stage. Nearly similar result found by Ananthararm VV in 2013. ${ }^{13}$

The study, shows that all respondents had heard about the pap smear which is similar with the study conducted by Ertem $G$ from Turkey and Singh E from Etawah, India. ${ }^{14-}$ ${ }^{15}$ In contrast, another study by Gupta $\mathrm{M}$ showed that only $19 \%$ had heard of Pap smear. ${ }^{12}$ Study conducted by Arulogun and Maxwell, Mutyaba et al and Anantharam VV that along with pap smear, majority of the respondents were aware of VILI and VIA whereas in present study, most of the respondent had knowledge only about pap smear and colposcopy. ${ }^{13,16,17}$

The major sources of information about cervical screening were media and books. Another study conducted by Awoele $\mathrm{O}$, observed that hospital worker is the major source of information followed by media. ${ }^{10}$

Though $89 \%$ have good attitude towards Pap smear, none of respondents had undergone Pap smear because they did not think of it as they do not have any symptoms of cervical cancer. This study showed that $15 \%$ respondents believed that Pap smear is painful, which also observed in study done by Wang PD in 2005. The low uptake of cervical cancer screening is very similar to many other studies. ${ }^{18-20}$

In this study, nurses wanted more information about cervical cancer screening. In the proposed diagnosis and treatment strategies there will be a need to integrate cervical cancer prevention issues in the nurses training curriculum, as they are the first port of entry into the health system.

\section{CONCLUSION}

This study showed that, female nursing staff had average knowledge and attitude towards cervical cancer but has limited understanding of different types of cervical cancer screening technique. Hence it is recommended that routine training in the form of lecture, seminar of the entire health care provider to be done on regular basis or done as a part of the orientation program to newly employed nursing staff. This will give an opportunity to make women more aware, comfortable and confident for screening tests. Moreover, if nurses themselves undergo screening test regularly, they can be role models for the other females.

\section{ACKNOWLEDGEMENTS}

Authors are extremely thankful to all the participants for their valuable contribution to carry out this study.

Funding: No funding sources

Conflict of interest: None declared

Ethical approval: The study was approved by the Institutional Ethics Committee

\section{REFERENCES}

1. Standard and Guidelines, Cervical and breast cancer screening by VIA and CBE. New York: The United Nations Population Fund; 2006.

2. Desai M. An assessment of community based cancer screening program among Indian women using the Anganwadi workers. J Obstet Gynecol India. 2004;54:483-7. 
3. Anorlu RI. Tumours of the cervix uteri. In: Agboola A ed. Text book of Obstetrics and Gynaecology for medical students. 2nd ed. Heinemann Educational Books (Nigeria) Plc, Ibadan; 2006:167-182.

4. Arevian M, Noureddine S, Kabakian-Khasholian T. Raising awareness and providing free screening improves cervical cancer screening among economically disadvantaged Lebanese/Armenian women. J Transcult Nurs. 2006;17:357-65.

5. Papanicolaou GN. A new procedure of staining vaginal smear. Sci. 1942;95:488.

6. O’Neal R. Cancer-stricken farrah fawcett weighs 86 pounds: Redmond O'Neal. Available from: www.thaindian.com/.../cancer-strickenfarrahfawcett-weighs-86-pounds-redmondoneal_100181396.html. USA: 2009.

7. Hand book on cancer. IARC 2003. Available from: www.iarc.fr/en/media-centre/pr/2003/index.

8. Dillner J, Rebolj M, Birembaut P, Petry KU, Szarewski A, Munk C, et al. Long term predictive values of cytology and human papillomavirus testing in cervical cancer screening: joint European cohort study. BMJ. 2008;337:a1754.

9. Ezem BU. Awareness and uptake of cervical cancer screening in Owerri, South-Eastern Nigeria. Ann Afr Med. 2007;6(3):94-8.

10. Awodele O, Adeyomoye AA, Awodele DF, Kwashi V, Awodele IO, Dolapo DC. A study on cervical cancer screening amongst nurses in Lagos University Teaching Hospital, Lagos, Nigeria. J Cancer Educ. 2011;26:497-504.

11. Mandelblatt JS. Is HIV infection a cofactor for cervical squamous cell neoplasia? Cancer Epidemiol Biomark Prev. 1999;8:97-106.

12. Gupta M, Yadav M, Agarwal N, Arora R. Awareness of cervical cancer screening among paramedical staff and students in an institution of northern India. Natl J Comm Med. 2013;4(2):333-6.

13. Anantharaman VV, Sudharshini S, Chitra A. A cross-sectional study on knowledge, attitude, and practice on cervical cancer and screening among female health care providers of Chennai Corporation, 2013. J Acad Med Sci. 2012;2:124-8.

14. Ertem G. Awareness of cervical cancer risk factors and screening behaviour among nurses in a rural region of Turkey. Asian Pac J Cancer Prev. 2009;10:735-8.

15. Singh E, Seth S, Rani V, Srivastava DK. Awareness of cervical cancer screening among nursing staff in a tertiary institution of rural India. J Gynecol Oncol. 2012;23(3):141-6.

16. Mutyaba T, Mmiro FA, Weiderpass E. Knowledge, attitudes and practices on cervical cancer screening among the medical workers of Mulago Hospital, Uganda. BMC Med Edu. 2006;6:13.

17. Arulogun OS, Maxwell OO. Perception and utilization of cervical cancer screening services among female nurses in University College Hospital, Ibadan, Nigeria. Pan Afr Med J. 2012;11:69.

18. Udigwe GO. Knowledge, attitude and practice of cervical cancer screening (pap smear) among female nurses in Nnewi, South Eastern Nigeria. Niger J Clin Pract. 2006;9:40-3.

19. Thippeveeranna C, Mohan SS, Singh LR, Singh NN. Knowledge, attitude and practice of the pap smear as a screening procedure among nurses in a tertiary hospital in North Eastern India. Asian Pac J Cancer Prev. 2013;14:849-52.

20. Gharoro EP, Ikeanyi EN. An appraisal of the level of awareness and utilization of the Pap smear as a cervical cancer screening test among female health workers in a tertiary health institution. Int J Gynecol Cancer. 2006;16:1063-8.

Cite this article as: Pegu B, Dhiman N, Chaturvedi J, Sharma SK. Nurse's knowledge and attitude regarding cervical cancer screening at a tertiary care hospital. Int J Reprod Contracept Obstet Gynecol 2017;6:907-10. 